\title{
Editorial
}

\section{The Cost of Pooling Tax Revenue}

\author{
Barry Bracewell-Milnes, Banstead
}

At the time of writing this editorial, the economic news was dominated by the threatened collapse and disappearance of the Exchange Rate Mechanism of the European Monetary System. Although this is in the first instance a phenomenon of monetary policy, it has important fiscal implications.

Exchange rate turbulence has a fiscal cause. There was no such turbulence under the gold standard before the first World War. This was because governments were much less heavily involved in their economies than they are now. At present the British government is absorbing more than half the national income in its expenditure and a number of European countries are well above Britain by this criterion; national income falls short of gross national product by the amount of capital consumption (or depreciation), so that the percentage of national income represented by government spending is several points higher than the percentage of gross domestic product and it is a correspondingly more reliable indicator. With government taking well over half national income in many countries, the adjustment to changing circumstances required of the private sector (and thus of the exchange rate) is twice as severe or more than it would be if the government take from the economy were restricted to a biblical tenth.

The problem is aggravated by the general although not universal practice of pooling government revenues from whatever source rather than earmarking them for particular purposes. This practice of pooling became established during periods when the government take was much nearer a biblical tenth than it is today; and it rested on the theoretical assumption of an efficient political process in which the wishes of democratic electors are translated into the actions of legislatures and governments. Both these forms of intellectual underpinning are now unreliable, as governments absorb more than half national income in response to the activities of pressure groups rather than the requirements of public opinion.

Public Choice theory, associated with the names of Professors James Buchanan and Gordon Tullock and at least one Nobel Prize, has identified and measured the gap between democratic theory and practice in translating popular wishes into government action. The democratic market is more 'imperfect' than almost any economic market. The traditional government argument against earmarking tax revenue and in favour of pooling is thus stood on its head: earmarking is more economically efficient than the pooling of tax revenue, not less.

Earmarking is supported by the benefit principle of public finance, that the justification of tax is that the individual receives from the government benefits broadly proportional to what he has paid as a taxpayer. Benefit theory was developed before universal suffrage (including suffrage for women) and was submerged by hopes or expectations that universal suffrage would deliver economically efficient results. These hopes and expectations have been disproved by events; it is time that benefit theory was reinstated.

Earmarking is the instrument by which the benefit principle is realised. Possible forms of earmarking (always as an alternative to the pooling of tax revenue) have been identified in The Case for Earmarked Taxes (Institute of Economic Affairs, London, 1991) and include:

- tax reliefs, especially for health and educational provision;

- vouchers;

- taxes giving entitlement to a benefit (parafiscal charges);

- compulsory loans;

- charges;

- lotteries;

- road pricing.

The cost of pooling tax revenue is the cost of ignoring Public Choice theory and pretending that the dynamics of decision-making and the quality of public debate are the same if the government is appropriating over half the national income for its own spending as if it is 
appropriating a tenth. It is the cost of failing to treat the taxpayer as a customer and treating him instead as a captive.

Earmarking of tax revenue for purposes with which the taxpayer can identify, by contrast, offers a prospect of bringing government expenditure under control and returning to the more rational system of a hundred years ago, when stable rates of exchange between currencies were not continually under threat from the excessive size of the government sector of the economy, which in practice makes little or no contribution to the readjustments required between one national economy and another. 